Walderzak

\title{
Blaming the Poor: The False Allure of the Capitalist Critique in the Age of Postmodernism
}

This article considers The Dark Knight Rises (Christopher Nolan, 2012) in order to argue through Fredric Jameson that postmodern aspects of a text are capable of obfuscating, if not altogether obliterating, any Marxist polemics. The first portion engages with Jameson's The Political Unconscious, particularly his emphasis on class struggle and identification of ideologemes which manifest in the text. The subsequent section considers The Dark Knight Rises as a postmodern text through Jameson's concepts of pastiche and nostalgia. Moreover, The Dark Knight Rises is contextualized within the recent spate of class-oriented cinema. Collectively, the goal is to identify a trend within such films of establishing a correlation between capitalism and inequality, ideologemes and postmodernism. The final result is an increasingly impressive group of genre-spanning films which address contemporary inequality in its multifarious forms, but which treat these issues more so as narrative devices than tenable critiques of the sites of oppression.

Keywords

FILM STUDIES

FREDRIC JAMESON

CLASS ANALYSIS

SCIENCE FICTION FILMS

GENRE STUDIES

MARXIST ANALYSIS

CLASS IDEOLOGY

FILM ANALYSIS

Joseph Walderzak is a faculty member at Adrian College. He also frequently teaches courses in film studies throughout the metro Detroit area. His scholarship most often focuses on gender and class across particular film genres. His work on the teen film genre was recently published in Quarterly Review of Film and Video and his work on the damsel within the superhero genre has been published in journals and anthologized. He is working on a book manuscript concerning representation of women detectives on television from 1980-2010. 
Fredric Jameson's "Postmodernism and Consumer Society" concludes by questioning whether texts produced in the age of postmodernism-a paradigm Jameson posits replicates and reinforces "the logic of consumer capitalism" - has the capacity to resist those very forces (Jameson 1963, 1860). Putting aside the facetiously rhetorical nature of Jameson's query, one only has to explore Jameson's The Political Unconscious to find a methodology which implicitly anticipates and answers Jameson's quandary. Through viewing Marxist criticism as the "ultimate semantic precondition for the intelligibility of literary and cultural texts," Jameson establishes an analytical approach capable of identifying the resistant elements of a postmodern text $(1981,75)$. Therefore, Jameson's Marxist analysis and his postmodern pessimism provides a theoretical antinomy which, rather paradoxically, jointly deployed forms a vital methodology for approaching texts which contain explicit Marxist imagery yet provide dichotomous interpretations from scholars and critics unable to reconcile the resistant narrative elements from those aspects (or denouements) which reinforce capitalist values. Over the last decade, the class-conscious film - a term used liberally to describe films with explicit or explicitly allegorical classbased narratives - has proliferated across an array of genres. These films provide narratives which reify Jameson's Marxist analysis as much as they illuminate his concerns over a postmodern "society that has become incapable of dealing with time and history" (Jameson 1981, 1860). I consider The Dark Knight Rises (Christopher Nolan, 2012), the most commercially successful of the recent blitz of class-conscious cinema, in order to argue through Jameson that the postmodern aspects of a text are capable of obfuscating, if not altogether obliterating, any Marxist polemics. Scholars who proffer contradictory narrative interpretations of class-conscious films-Marxist frequently identify how explicitly foregrounding class inequality often upholds the ruling discourse of consumer capitalism-would benefit from identifying how these contradictions are often the result of its postmodern aesthetics.

To prove such a contention, this article is divided along two theoretical impulses. In the first portion, I engage with Jameson's The Political Unconscious, particularly his emphasis on class struggle and the identification of ideologemes which manifest in the text. In the subsequent portion, I position The Dark Knight Rises as a postmodern text through Jameson's concepts of pastiche and nostalgia as described in "Postmodernism and Consumer Society." Moreover, I contextualize The Dark Knight Rises within the recent spate of classoriented cinema through an analysis of two highly representative films: the gangster allegory Killing Them Softly (Andrew Dominik, 2012) and the post-apocalyptic thriller Snowpiercer (Bong Joon-ho, 2013). Collectively, the goal is to identify a trend within such films of establishing a correlation between capitalism and inequality, ideologemes and postmodernism. Yet, equally present is a causation between heroism and capitalism, particularly the tenets of self-reliance, ingenuity, and economic ascendancy. The final result is an increasingly large group of genre-spanning films which address contemporary inequality in its multifarious forms, but which treat these issues more so as narrative devices than tenable critiques of the sites of oppression. Ultimately, this somewhat bifurcated approach is only as successful as its ability to illustrate the deleterious relationship between postmodernism and representations of class struggle. 
The foregrounding of Jameson's scholarship is not in itself an effort to avoid contemporary debates on class analysis, although I recognize that the majority of these debates fall into niche discussions on issues such as nostalgia and historical memory that lack relevancy to this specific matter. Rather, this work is interested in illuminating how Jameson's theoriesmany of which are foundational to class analysis of cinema-require new attention in a moment in which there is a surfeit of contemporary scholarship on class in film. As textual film analysis becomes increasingly preoccupied with issues of identity, the topic of class is often severed from these discussions. In other cases, class is subordinate to issues of race and sexuality in understanding and criticizing representational politics. This ancillary position of class is perhaps inevitable given the importance and relevance of identity politics; this analysis should not be viewed as severed from these debates but rather offers a more developed and refined look at how critiques of capitalism are often flawed. This article's greatest ambition resides in its ability to construct a method for acknowledging how postmodernism affects and limits all forms of cultural critique within cinema. Therefore, Jameson's relevancy is not restricted to the intersection of class politics and cinema but applies equally to any progressive narrative element which is contradicted by postmodern aesthetics. Moreover, the current sociopolitical moment, with rising inequality and pervasive cultural division, is not at all unlike the 1980s; if ever there was a moment to resurrect and revisit texts that have been presumably embedded into contemporary thought, it would be such moments where history appears hopelessly cyclical.

To a certain extent, any film which grosses over a billion dollars - with the advertising that requires and the cross media ventures it implies - is unlikely to form a cohesive ideology oppositional to the economic and political paradigm which produced the text. Jameson plainly summarizes this predicament by arguing that texts which survive usually uphold the ruling voice; a product designed to make money, no matter its artistic attributes, inherits and embraces the economic and political discourses of its creation. Therefore, it is not the text itself-the apotheosis of consumer capitalismthat can provide antagonist dialogue, but through a narrative that has the potential to contest and undermine ruling class ideology rather than seek legitimation. David Brooks expands on this dynamic when claiming "cinema is the supreme maker and manipulator of images," but "mimetic qualities of cinema of this sort are extraordinary revealing;" postmodern films "must self-consciously embrace the problem of image creation" $(2013,323)$. The Political Unconscious provides three Marxist methodological horizons to explore a text: the allegorical or symbolic act, the collective class discourse, and the mode of production. The Dark Knight Rises operates most notably as part of the collective class discourse, a part which consists of what is identified by Jameson as ideologemes that, in combination, form an ideology of form. For Jameson, the ideologeme is the smallest unit of the struggle between the classes that contributes to the antagonistic discourse (1981, 76). The film text itself is an ideologeme but more fundamental is an analysis of scenes which repeatedly engage with concepts of class conflict. The Dark Knight Rises' primary ideologeme involves the dichotomy between rich and poor, a bifurcated presentation of social classes which aligns with Jameson's interpretation of Marx.

Importantly, the film's villains are frequently the voice of the oppressed. 


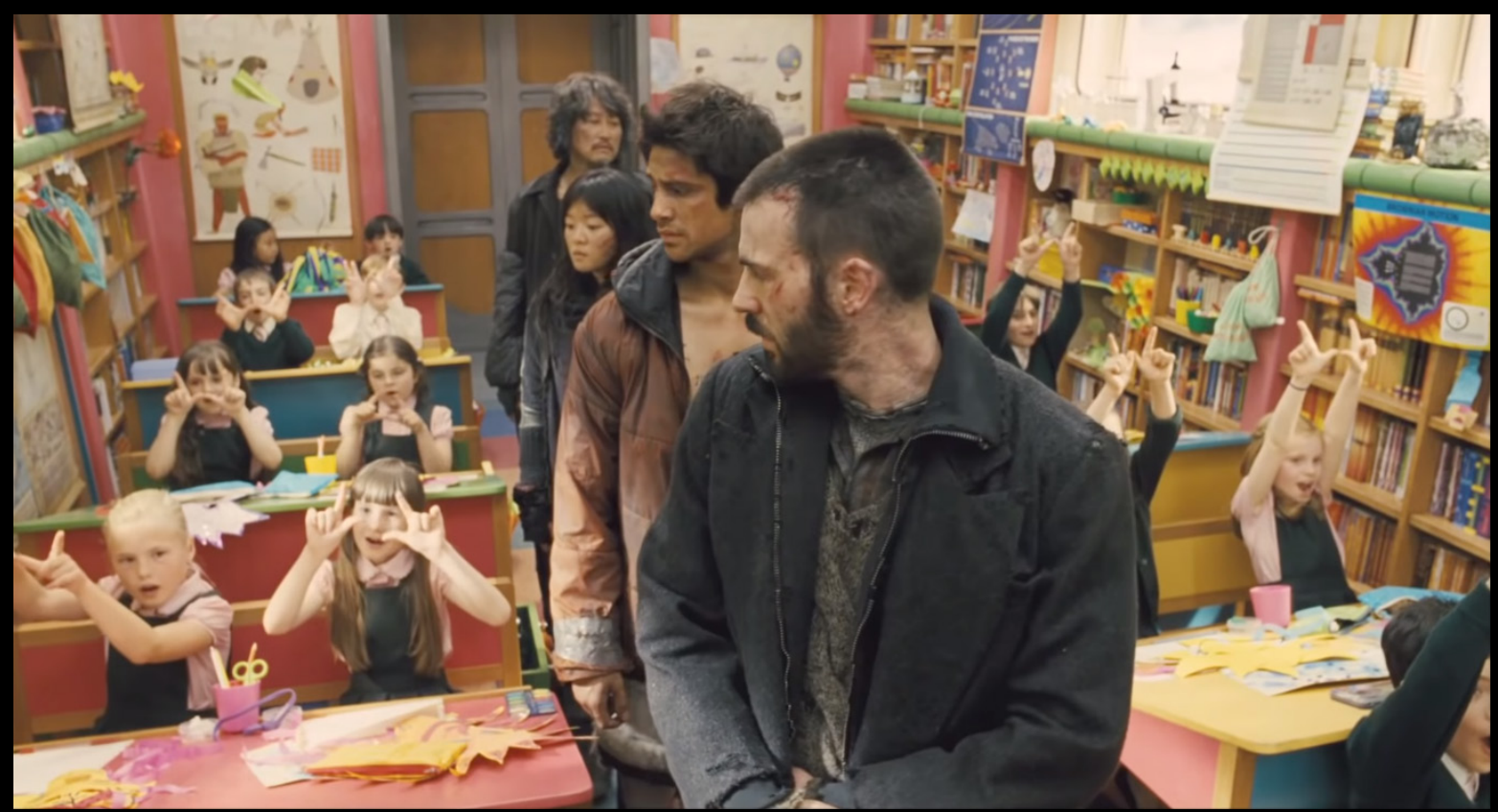

Fig. 1: Students make the letter "W" to extol the leader Wilford, as members of the working class migrate towards the engine. Snowpiercer (Bong Joon-ho, 2013)

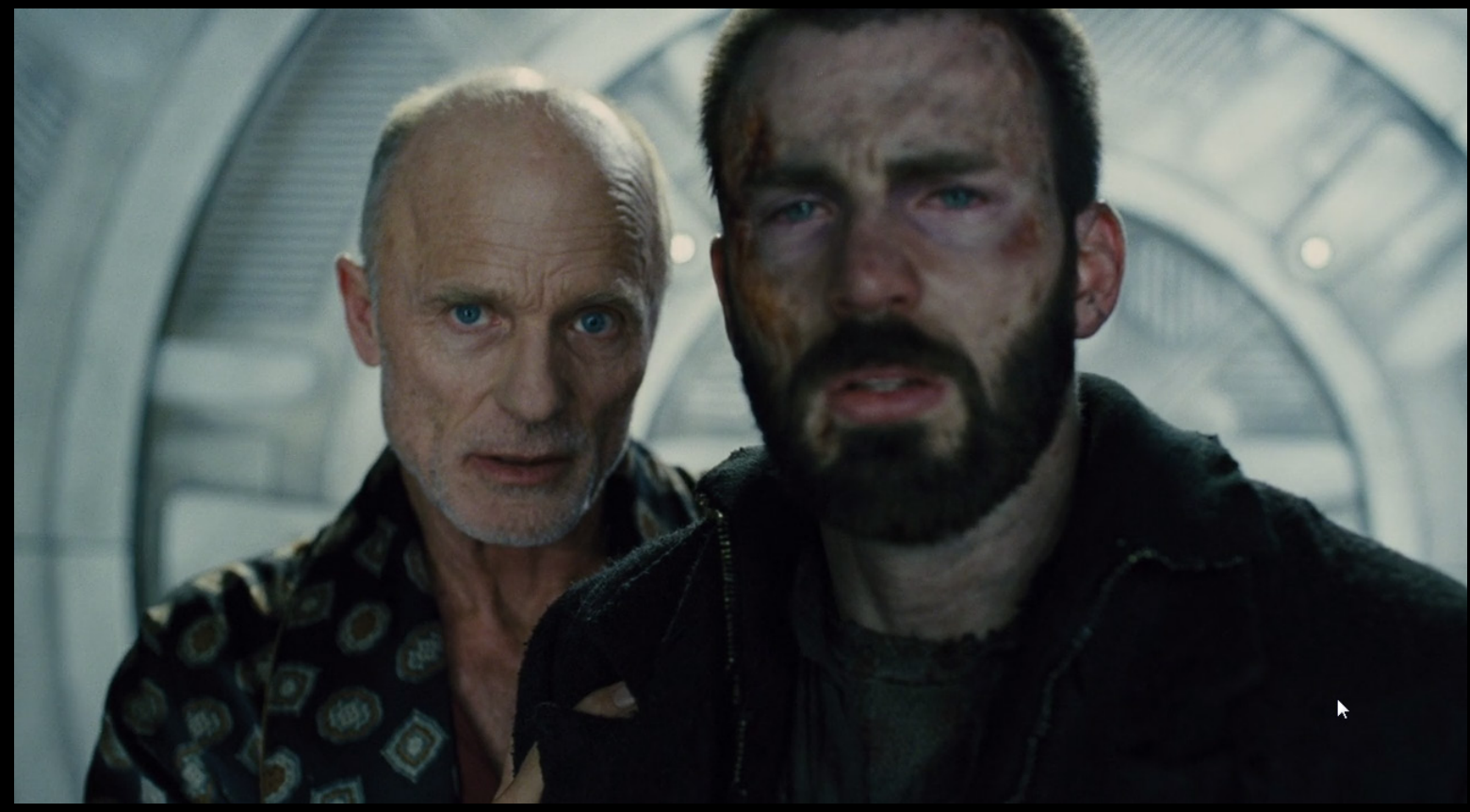

Fig. 2: In Snowpiercer's denouement, Curtis is left to recognize the complicity of the working class with the ruling class, while serving as a spectator to the aimless brutality. Snowpiercer (Bong Joon-ho, 2013) 
Selina Kyle (Anne Hathaway), the thief better known as Catwoman, challenges Bruce Wayne's, the hero Batman (Christian Bale), ruling class values. She justifies her legerdemain by positing that, "I take what I need from those who have more than enough." Later in her exchange with Wayne, she threatens that, "you're all going to wonder how you could live so large and leave so little for the rest of us." Elsewhere, after Wayne has been swindled out of his fortune but is left his enormous estate, Kyle quips the "rich don't even go broke like the rest of us." The film's primary villain, Bane (Tom Hardy), likewise questions the morality of how wealth is amassed. When invading a stock exchange, an investor condescendingly explains to Bane that there is no money to be stolen to which he replies, "Really? Then why are you people here?" After Bane has gained control of Gotham, the financial backer he has duped with promises of pathways to greater financial power attempts to assert his control by claiming that he has paid Bane a small fortune to which he retorts-only seconds before executing him-“"And this gives you power over me?" Later, with Bane's hold on the city established, further wealthy cronies are sentenced to death for "living off the blood and sweat of others," a presumably intentional reference to Marx's concept of primitive accumulation.

If The Dark Knight Rises' villains espouse Marxist views, the reversal in the post-apocalyptic action film Snowpiercer would ostensibly gratify the desire for class ideologemes. Mason (Tilda Swinton), the film's most visible villain, pontificates on how everyone must abide to the eternal order and "occupy our preordained particular position." If Bane and Selina Kyle paraphrase Marx, then Mason similarly borrows from Weber's Protestant Work Ethic. Mason, when attempting to stymy the rebellion which propels the film's narrative, speaks of the "misplaced optimism of the doomed" and provides a perfect aphorism for the American Dream. Snowpiercer's villains are not pedaling the myths of capitalist society but rather present it as the only option and the system which best conforms to human capacity. Focusing on the only survivors of an environmental catastrophe who are left bound to a train, the only alternative to the train's economic system is presented as an almost immediate death in frigid temperatures. The passengers of the back of the train, who labor in squalid conditions for slimy black bars of "protein" and face violent oppression from Mason's cronies, forge ahead with a plan to revolt and take power over the "engine;" the failure to do so has doomed all past revolutions the audience is told. The allegorical antagonistic elements of the ideologeme become instantly clear: Mason is the ruling class; the last train, led by Curtis (Chris Evans), is the proletariat; the engine is the capitalist system. The vast majority of the film follows the logic of class warfare. Each subsequent car in the train is more lavish and hedonistic, providing a new facet of capitalist society to dissect and critique. Curtis' followers are exposed to food they thought no longer existed and comforts they could hardly imagine (saunas and hot tubs). The ideologeme formed in a classroom towards the head of the train proves remarkably cogent as it identifies how the educational system brazenly inculcates students on the virtues of the "engine" (again, capitalism) and beatifies its inventor and target of the revolt, the mysterious Wilford (Ed Harris) (Fig. 1).

Even if each new ideologeme is left segmented between interspersions of sustained choreographed violence (in a style extremely reminiscent of fellow South Korean filmmaker Chan- 
wook Park's Oldboy [Oldeuboi, 2003]), the persistence of the antagonism overshadows these diversions. In fact, the violent interludes may help to reduce the potentially maladroit character of the ideologemes. It is a necessary respite for those who find these sections-much like the aforementioned classroom car scene-pedantic and overtly political. What disrupts the clear procession of ideologemes from coalescing into a class-conscious film, is the film's climatic confrontation between Curtis and Wilford which demonstrates either a lack of commitment to the film's ideology in favoring the thrill of an illogical plot twist, or exemplifies the postmodern film in that the previous ideologemes are merely hollow provocation. For Wilford confides to Curtis that he had devised and orchestrated the revolt-and previous failed iterations-with Gilliam (John

Hurt), Curtis' frail mentor and the leader of the back of the train. Wilford uses the revolt as a population purge to expedite natural selection. In partnership with Gilliam, Wilford is able to maintain the proper mix of "anxiety and fear" to control the population. With this revelation, and because of the steady train (if, I may) of ideologemes, Gilliam's involvement is tantamount to the proletariat being complicit with the ruling class that subordinates them. Before one can imagine a reading that is less subversive, Wilford and Curtis watch as people viciously attack one another. Calmly, Wilford comments, "that's who people are" (Fig. 2). The interpretation, if there deserves to be one, is clear: capitalism is the only option because it best caters to the depravity that is human nature. Thus, the audience is bestowed not an antagonistic ideologeme but an all too familiar refrain. One is left only to imagine a narrative twist which revealed Wilford to be a fraud and that his life-saving prowess of engineering, glorified in the train's classroom, was nothing more than another act of exploitation. Tellingly, the only two who see the potential for life beyond the train are a couple who open the doors of the train in exchange for a drug, which keeps them in a stupor and ultimately provides their freedom.

Killing Them Softly may deal in ideologemes of capitalist inequality with an audacious lack of subtlety but its audacity similarly fails to conjure a cohesive polemic. Using the context of the 2008 recession, the film deploys the gangster formula as a parallel for the American political and economic system; in short, American capitalism is tantamount to living in a gangster film where the only means of survival are brutality, depravity, and cheating. The last lines of the film, recited by a sympathetic hit-man (Brad Pitt) while watching Obama's inauguration and anticipating every hackneyed adage, succinctly encapsulate the film: "This guy [Obama] wants to tell me we're living in a community. Don't make me laugh. I'm living in America and in America you're on your own. America's not a country; it's just a business. Now fucking pay me." The juxtaposition between the gangster narrative and the news coverage of the economic turmoil of 2008 ubiquitously characterizes the film: during an armed robbery President Bush gives a speech about economic collapse; while a pair of mobsters talk about maintaining the "public image," Ben Bernanke is heard over the radio speaking on maintaining confidence in financial systems; prior to embarking on the film's penultimate murder, Bush speaks on how America has the most talent in the world. This pervasive juxtaposition is provocative and seemingly the antagonistic relationship between news coverage and gangster film tropes would result in an irreproachable ideologeme. Rather than creating a dialectical montage with these conflicting elements, however, 
the film parades its allegorical imagery in sophist pageantry. The two criminals whose robbery initiates the film's plot are characterized as desperate equally as they are as incompetent and indolent. These are hardly sympathetic characters who are the victims of the American economic system which imbues the films diegesis. If the gangster film is an allegory for the American corporate capitalism, it is striking how this is the exceptional gangster film absent non-mob victims, spouses, or children. Killing Them Softly provides a hermetically sealed gangster environment that eschews the cultural context necessary to form an ideologeme. The dogged efforts to juxtapose organized (or, perhaps, hierarchal) crime and politicians ultimately proves reactionary. At the moment when every character in the diegetic and non-diegetic world is corrupt or immoral, while being severed from the context of the cause of suffering, what room is there to explore the class antagonism essential to the ideologeme. David Harvey observes that "the reduction of art to a test stressing discontinuity and allegory, poses all kinds of problems for aesthetic and critical judgment" $(1990,56)$. Unlike Snowpiercer's unique allegory that is only somewhat distorted by its environmental cautionary tale, allegory which must conform to the rigid structures of genre formula reduces capitalist inequality to forms bound by those very formulae.

To return to The Dark Knight Rises, Kyle and Bane justify their criminality through the rational of pervasive inequality; their actions are legitimized through articulating a class view that echoes Jameson's (1981) interpretation of Marx in which sociological subgroups are jettisoned in favor of a dichotomy of rulers and oppositions. In this case, the overtly simplistic dichotomy between heroes and villains in comic books films lends itself well to a Marxist discourse. What is problematic and what has inspired drastically different interpretations of Batman films generally is that the oppositional forces-those who are identifying the inequality of the capitalist system-are the villains of the film. A few notable exceptions exist such as when the, albeit meek and cowardly, Police Captain (Mathew Modine) refuses to risk his men to save "someone else's money" during the stock market siege. However, the film does consistently put the oppositional language in the mouths of the film's villains. Whether this means the film is implicitly endorsing ruling class values through associating them with the film's titular hero or simply marginalizing the opposition to the voice of villains in order to characterize its position in society is a site of confusion that Jameson's ideologeme fails to entirely rectify. Furthermore, the sympathetic nature of the villainsKyle becomes an ambivalent hero by the film's conclusion and Bane is nothing more than a pawn in Miranda Tate's masterplan-complicates issues of interpretation. Before revealing her role in the take-over of Gotham, Tate (Marion Cotillard) - herself a wealthy board member of Wayne Industries-criticizes a peer for merely understanding "money and the power you think it buys." Is the voice of opposition to capitalist values and inequality as sympathetic as it is stigmatized through its association with villainy? Bane liberates the city in an effort to give control back to the people and-again evoking neo-Marxist language-speaks of the myths of opportunity and the institutions of oppression. Before one can freely associate those beliefs with the evil dichotomous to Wayne and Batman's manifestation of good, it is revealed that Bane's emancipation is false and he truly wishes to inspire chaos and hope before destroying the 
city. That the rhetoric of inequality is confined to the film's villains and that this ideology is compromised by its narrative insincerity does obfuscate meaning. Ideologemes materialize through this rhetoric and through the dichotomies it erects, but the narrative contradictions fail to manifest an ideology of form. The film's ideologeme remains provocative; the politics of the film do not require cohesiveness in order to contribute to the antagonistic class discourse. Yet, the extent of the ideologemes contribution is limited not only by this narrative confusion but by the film's conspicuous adoption of postmodern attitudes and aesthetics. While Jameson's argument specifically concerns identifying a text's hidden resistant elements, I find the self-consciously Marxist imagery obfuscates such elements; that such elements can even manifest in a way to contradict these explicit elements seems altogether doubtful.

For Bane to give the people hope is the ultimate punishment and it is this type of narrative element which conjures Jameson's conception of postmodernism. Before considering how Jameson's concepts of pastiche and nostalgia pervade the film and firmly entrench it within a postmodern aesthetic, it is important to position the narrative within this paradigm as well. "You have a practiced apathy," Miranda Tate quips to Wayne who elsewhere is described by his butler and confidant Alfred Pennyworth (Michael Caine) as "not living but just waiting for something bad to happen." Bane recognizes that Wayne does not fear death and that his only course to torture his soul is to provide him with a sense of hope he has lost; without the fear of death, Wayne has been left conspicuously detached and therefore impervious. Jameson (1983) observes the death of the philosophical individual at the dawn of postmodernism. While
Jameson is far more concerned with how this philosophical development affects writers and artists who have been sapped of ambition, Wayne's ennui-notably not assuaged by his massive wealth or privilege-is another symptom of the death of the individual, and the ambition intrinsic to its existence.

Further, The Dark Knight Rises is laden with a loss of faith in institutions. Wayne will not move forward with his ability to provide clean energy to the entire city because he fears - and his fears are realized - that it could be weaponized, “one man's tool is another man's weapon" he explains. Detective Blake (Joseph Gordon-Levitt), Wayne's trusted ally, throws his badge into the river as a symbolic gesture of his lost faith in the criminal justice institution. Likewise, Commissioner Gordon (Gary Oldman) speaks of the "structures becoming shackles" in his justification of fabricating a heroic mythology around a fallen figure in order to wield authoritative justice; that Gordon's refrain again seems to summon Marx's infamous "nothing to lose but their chains," only further complicates the formation of a cohesive ideologeme. The federal government receives no reprieve from these indictments as it is unwilling to provide a solution for the pending destruction of Gotham, endorsing the villain's description of the city as of meager hope and beyond saving. These fears and the lack of faith in institutions exemplify the historical shift to postmodernism as described by Jameson (1983). Importantly, these films do not merit postmodern classification merely because of chronology, but they exemplify Jameson's theoretical definitions.

What most compromises the formation of ideology and an antagonistic discourse is how the film adopts pastiche and nostalgia in order to further dehistoricize the narrative. The cinematic Gotham is 


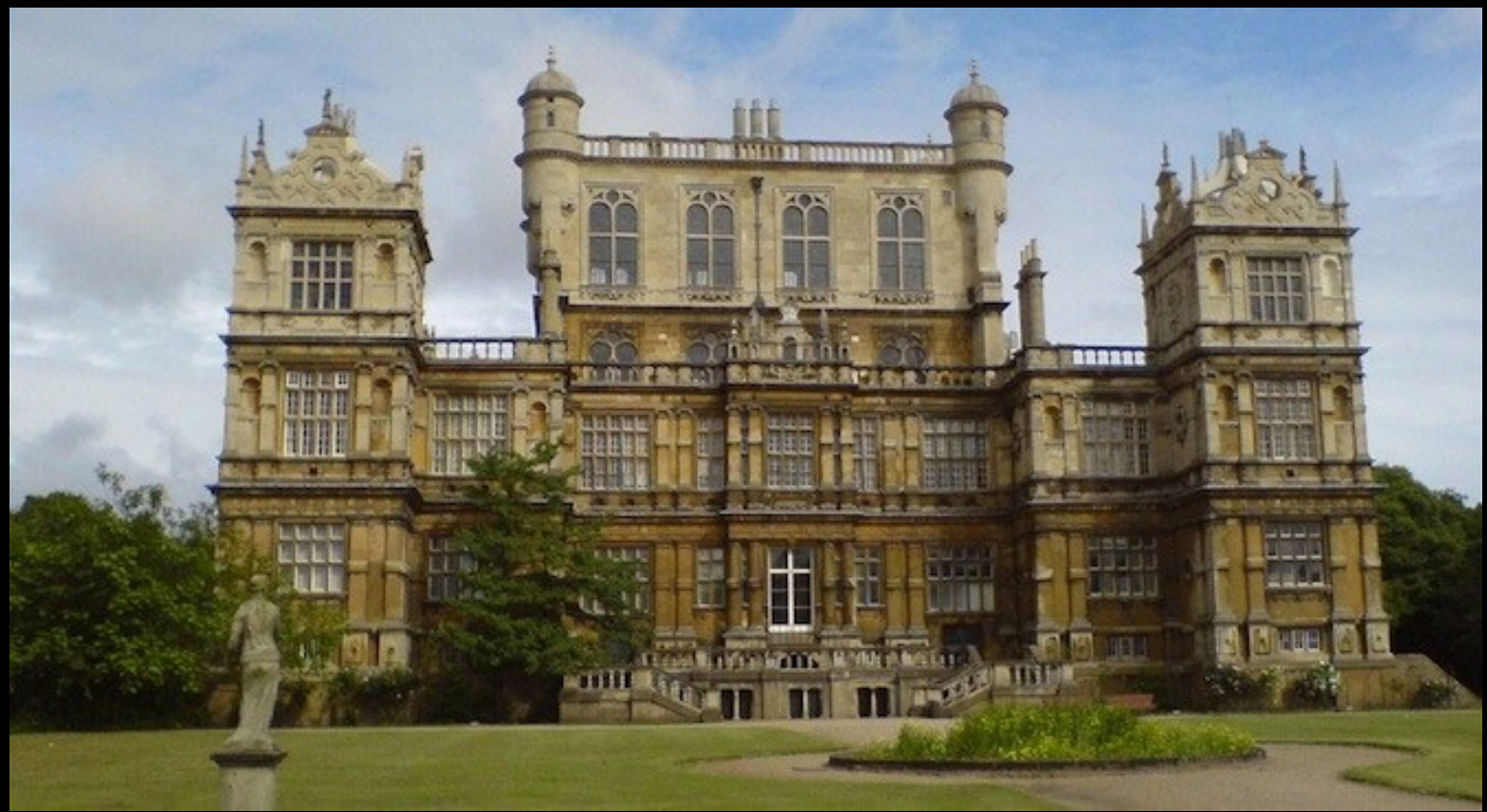

Figure 3: As distinctly English as can be imagined, yet existing on the outskirts of Gotham, a New York City inspired metropolitan area. The Dark Knight Rises (Christopher Nolan, 2012) 
placeless without any real identity, suggestive of the hyperspace described by Jameson in his assessment of postmodern architecture. The interiors and exteriors alike are-to deploy a hallmark of Jean-François Lyotard's conception of postmodernism-a bricolage of recognizable international cities including New York, Los Angeles, London and Pittsburgh. What results is an absolute blurring of Harvey's triumvirate of types of space-real, represented, inner-which itself defines the postmodern condition (1990, 218-22). Wayne manor itself is entirely anachronistic; the style is early 20 th century but resembles nothing which ever existed in the United States-a postmodern construct of a false past (Fig. 3). This series of recognizable architectural structures in an unrecognizable present fully embodies "the great global multinational ... network in which we find ourselves caught as individuals" and which transcends "the capacities of the individual human body to locate itself" (Jameson 1983, 1857). The audience is "treated to a picture of the urban that is, in the fashion of postmodern society, entirely declasse, much closer to Simmel than Marx" (Brooks, 316). As much as geography and architecture create a dehistoricized postmodern setting, time is also a site of tremendous alacrity. Blake was raised in an orphanage which was endowed by Wayne and a substantial subplot involves Blake's relationship with this institution. In the film's end, Wayne donates his estate to become an orphanage for boys. Of course, the orphanage model was abandoned in the United States by the 1960s and this relic from the past muddles comprehension of any Marxist polemic. In other scenes, Gotham police cars appear to be long outdated, the Gotham football team consists of recognizable current and past Pittsburgh Steelers, and Wayne-after being caught by
Bane - is dropped into a prison pit in a "more ancient part of the world," a descriptor as equally vague as the nebulous visual clues.

The only legitimate sign of the 21st century is the modern technology but even this facet does not locate it in a particular historical moment; in fact, the diversity of locales and times situates it in a future placeless context as much as a contemporary one. One can assume Gotham is a stand-in for New York City, given its etymology, and the inequality relates to the United States own economic divisions, but this is not meaningfully imbued in the filmic text. It is-in Jameson's language - a pastiche of the modern city; it is void of satirical impulses but is nothing more than "immense fragmentation" of images which results in a stylistic heterogeneity (1983, 1849). This maelstrom of pastiche and nostalgia is, rather notably, perhaps an intrinsic part of the comic book cinema culture. Wilson Koh (2009) successfully complicates the politics of Spider-Man by similarly positing it is drenched in a nostalgic comic book heritage. Yet, Spider-Man's themes of duty and responsibility are enhanced by this nostalgia, whereas the gritty "realistic" aesthetic of Dark Knight Rises are compromised by this same nostalgic tendency.

The donning of masks - both of Batman and Bruce Wayne-is a liminal condition that anticipated the postmodern condition as much as it is a product of it. Moreover, the seriality of the comic book hero inevitably evokes nostalgia and The Dark Knight Rises solicits these emotions through subtle references to comic book canon and lore as well as conspicuous exercises of self-referentiality to previous iterations which exist in the same timeline or "universe." The film is far more obligated to producing a particular nostalgia and pastiche which eschews contemporary culture in favor 
of its own fictional lineage. As such, the film has a metonymic relationship with its contemporary historical moment and the issues of inequality and class conflict can be understood as arbitrary; the nostalgia for its own lineage and the various times and places which best represent these determinant themes influence an inability "of achieving aesthetic representations of our own current experience" (Jameson 1983, 1853).

Snowpiercer and Killing Them Softly both share in this deluge of pastiche and bricolage and, like The Dark Knight Rises, suffer to form ideologemes because of this postmodern condition. The setting of Killing Them Softly is never entirely clear. Neighborhoods of Boston are mentioned but it was shot in New Orleans, a fact that seems to be alluded to by scenes where characters wander streets lined with detritus and through city streets that appear ravaged far more by Hurricane Katrina than by generations of penury. Likewise, the character's cars are all more than thirty years old, the clumsy mistake of a film crew oblivious of how the automotive iconography of poverty does not resemble cars that are considered vintage collectibles. Meanwhile, the procession of news reports firmly places the film in 2008, but anyone with more than a passing recollection of the timeline of events would notice that the various radio and television broadcasts span a timeline vastly greater than the short timeline of the narrative. With a lack of place and a contradictory sense of time, the film is embroiled in a maelstrom of postmodern imagery. More distractingly, the film's cast is laden with extratextual interpretations. James Gandolfini's hapless and cruel hit-man can hardly exist without a recollection of his iconic Tony Soprano. Ray Liotta's character, feeble and unimportant, provides a stark contrast to his most notable role of Henry Hill (Goodfellas [Martin Scorsese, 1990]).
The filmgoer uninitiated to these hallmarks of the genre would be an exception and the expected common result is a film which is too entangled in its own generic heritage for allegorical ideologemes to manifest. Star personas in the latter half of film history are predicated equally on individual film roles as they are on public personas. Thus, intertextuality and cinephilia manifest in a postmodern condition in which resistance meanings suffer.

The source material of Snowpiercer, the French graphic novel Le Transperceneige (Jacques Lob and Jean-Marc Rochette, 1982), is adapted into an entirely different cultural context and time period. The class struggle is integral to the narrative, but the environmental impetus of the story is entirely magnified in the context of 2013, in which the catastrophic effects of global warming are in fruition. Killing Them Softly also lifts its narrative from its source material (the novel Cogan's Trade [George Higgins, 1974]), but there is far more congruency between the economic stagnation of the 1970s and the narrative about the regulation of the underground card games. If the death of originality is a symptom of the postmodern, then the adaptation of source material into modern contexts-no matter the cultural discrepancies - is the unfortunate most alluring of the surviving options.

Jameson (1983) describes nostalgia as a "colonizing" force that is "an alarming and pathological symptom of a society that has become incapable of dealing with time and history" (1983, 1853). Certainly, The Dark Knight Rises exists within a cinematic genre which is one of mutability and of a hyperreality that should not be expected to harmoniously coincide with any particular contemporary moment. Yet, what meaning is expected to be found in its explicitly class-conscious narrative? Or, in other words, how can a film such as The Dark Knight 
Rises contribute an ideologeme to the antagonist class discourse when its relation to nostalgia and postmodernity challenge those very intentions? This concern becomes more pressing when it is fully acknowledged that the vast majority of class critiques are relegated to genre films. The few exceptions often adopt the hyper-stylized aesthetics of genre films, such as The Wolf of Wall Street (Martin Scorsese, 2013) which works equally as a gangster film as it does a prestige drama. Jameson applauds the "critical, negative, contestatory, subversive, oppositional" aspects of modernist texts which have been muted as reality has been transformed into images and "the fragmentation of time" $(1983,1860)$. The Dark Knight Rises is a manifestation of these concerns and perhaps it is no surprise then that the narrative lacks a cohesive ideology or even an agreeable set of thematic principles. Allegories and symbolism have ideological power but only so far as they allude to a reality, a different time and place that provides clarity of the contemporary moment rather than distorts it. Yet, what room is there left in a postmodern society even for allegories when each image provided is capable of having existed in another context, another set of meanings contained within each image.

This body of films, of which the three examined in this article are far from exhaustive, prove to be extraordinarily reactionary and repressive. Much like the assumed male gaze identified by Laura Mulvey and expanded and refined by countless others, cinema equally assumes a capitalist (i.e. bourgeois) gaze. If the male audience simultaneously identifies with the male protagonist and objectifies the female characters in an act which reaffirms their own masculinity, similarly the audience is asked to identify with capitalism and vilify-as opposed to objectify - those characters that embody the rhetoric of Marx, revolution, or socialism. While these concepts are often conflated into one bourgeois gaze that relies on a masculinist perspective, these films hardly require a dominant perspective in order to be receptive to identifying with the capitalist position, no matter how marginalized it may be in the narrative. The process of affirming one's own masculine heterosexual desire is analogous to the process in which one affirms their own capitalist ideology. Even when reduced to hedonism and avarice, the affirmation of capitalism remains inevitable when all alternatives are ultimately presented as evil or impossible. The scopophilia pleasure derived from gazing at the female form is transformed into an equally pleasurable experience in viewing ideologemes which challenge capitalism, only to have them made obsolete through narrative contradiction or postmodern aesthetics. In other words, the economic system which is a source of misery and oppression is challenged (the audience revels in its villainous characterization) before it is resuscitated (the audience can be assured that their oppression is superior to all other alternatives). Rather than trying to erase economic oppression by inviting class blindness from the audience, the postmodern class-conscious film embraces the audiences' capitalist gaze in order to inculcate the virtues of its oppression.

Jameson's approach to Marxist ideology and postmodernism provides little hope for the coalescing of a truly transformative discourse oppositional to ruling class values without an explicit recognition of how postmodern aesthetics reduce antagonistic discourses to residual forms of history. The postmodern film is unable to answer Brooks' call for a consciously socialist current, instead conforming to the wave of "films, novels and plays 
that go so far... and no farther" (2013, 318). This is not solely nor principally the result of filmmakers unwilling to take risks. It is the ideologeme that is absent ideology; a paradox only made possible through postmodernism in the era of late capitalism. In a world inundated with media texts and saturated with pastiche, consumer capitalism is the benefactor and any oppositional force-including the class-conscious film -is marginalized by its unwilling participation in postmodern aesthetics.

1/ See Vincent M. Gaine's "Genre and Super-Heroism: Batman in the New Millennium" (2011), Will Brooker's Hunting the Dark Knight: Twenty-First Century Batman (2012) and Martin Fradley's "What Do You Believe In? Film Scholarship and the Cultural Politics of the Dark Knight Franchise" (2013).

\section{Bibliography}

Brooker, Will. 2012. Hunting the Dark Knight: Twenty-First Century Batman. New York and London: IB Tauris.

Brooks, David. 2013. The Sky Between the Leaves: Film Reviews, Essays \& Interviews 1992-2012. Oak Park, MI: Mehring Press.

Fradley, Martin. 2013. "What Do You Believe In? Film Scholarship and the Cultural Politics of the Dark Knight Franchise." Film Quarterly 66 (3): 15-27. https://doi.org/10.1525/fq.2013.66.3.15

Gaine, Vincent M. 2011. "Genre and Super-Heroism: Batman in the New Millennium." In The 21st Century Superhero: Essays on Gender, Genre, and Globalization in Film, edited by Richard J. Gray II \& Betty Kaklamanidou, 111-26. Jefferson, NC: McFarland.

Koh, Wilson. 2009. "Everything Old Is Good Again: Myth and Nostalgia in Spider-Man." Continuum: Journal Of Media and Cultural Studies 23 (5): 735-47. https://doi.org/10.1080/10304310903154651

Harvey, David. 1990. The Condition of Postmodernity: An Enquiry into the Origins of Cultural Change. Cambridge and Oxford: Blackwell.

Jameson, Fredric. 1981. The Political Unconscious. Ithaca: Cornell UP. 1983. "Postmodernism and Consumer Society." In The Norton Anthology of Theory \& Criticism, edited by Vincent B. Leitch, 1846-60. New York and London: W.W. Norton \& Company.

Lyotard, Jean-François. 1984. The Postmodern Condition: A Report on Knowledge. Minneapolis: University of Minnesota Press.

How to quote Walderzak, Joseph. 2020. "Blaming the Poor: The False Allure of the Capitalist Critique in the Age of Postmodernism." Comparative Cinema, Vol. VIII, No. 14, pp. 33-45. DOI: 10.31009/cc.2020. v8.i14.03 